\title{
COMPARISON OF ACTUAL AND PREDICTED AMINO ACID CONTENTS IN THE DUODENAL DIGESTA OF DAIRY COWS
}

\author{
M. Richter, J. Třináctý, L. Křížová
}

Received: March 23, 2010

\begin{abstract}
RICHTER, M., TŘINÁCTÝ, J., KŘİŽOVÁ, L.: Comparison of actual and predicted amino acid contents in the duodenal digesta of dairy cows. Acta univ. agric. et silvic. Mendel. Brun., 2010, LVIII, No. 5, pp. 313-320

In this experiment on three dairy cows with the ruminal and duodenal T-cannulas, the actual and predicted amino acid (AA) profiles of the protein fraction flowed to the small intestine were compared. The prediction was calculated by two methods: with the use of mean published AA profile of microbial protein and of experimentally determined one. The actual AA profile of digesta protein was corrected for glycine (Gly) of bile origin. In comparison to the published AA profile of microbial protein the use of the actual one did not contribute to an improvement of prediction accuracy (mean prediction error: 7.36 vs. $7.54 \%$, respectively). Inaccurate determination of AA composition of undegraded feed protein and the insufficient correction for Gly of bile origin were the probable sources of the residual variability.
\end{abstract}

amino acids, dairy cow, duodenum, microbial protein, prediction

As regards the requirement of crude protein, the diets for cattle are evaluated in the French PDI system (Jarrige, 1990) on the basis of prediction of the flow of protein truly digestible in the small intestine (PDI). This protein consists of two basic fractions: rumen undegraded feed protein (PDIA) and microbial protein (PDIM), the amount of which correlates with the fermentable part of feed. The equation to calculate the second fraction is depending upon whether the limiting factor of its formation is energy (PDIME: microbial protein digested in the intestine when rumen fermentable energy is limiting) or crude protein (PDIMN: microbial protein digested in the intestine when rumen fermentable nitrogen is limiting). The resulting predicted value of true digestible protein (PDIE, PDIN) is the sum of these two basic fractions provided by different components of the diet (Jarrige, 1989).

Even with a correct prediction of these values and subsequent balancing of PDI requirement, with some diets it is impossible to achieve maximum production of milk or meat. This is due to deficiencies of some amino acids (AA), which was confirmed e.g. by the duodenal infusion of Lys and Met in lac- tating cows fed on maize silage based diet (Schwab et al., 1992), or of His in cows fed grass silages (Vanhatalo et al., 1999). For this reason, a need to define the diet occurred, not only in terms of the flow of basic protein fraction, but also in terms of representation of individual especially essential AA in PDI. For this purpose, on the basis of the existing French PDI system, a consequential AADI system was proposed (Rulquin et al., 1993; Rulquin \& Vérité, 1993).

The final value of AADI (\% PDIE) of a given AA results from its content in the undegraded residue of feed protein and microbial mass protein formed in the rumen with contribution of the degraded feed components. Because PDI is constituted of more than $50 \%$ of microbial protein (Rulquin et al., 1998) and because of large differences in AA profile of bacteria protein (Clark et al., 1992; Rulquin \& Vérité, 1993), the main source of variability of predicted AADI values is microbial mass.

The aim of this study was to compare the experimental and predicted AA profiles of the digesta entering the small intestine using the method described by Rulquin et al. (1998) and compare the accuracy of prediction when using the pub- 
lished mean (Le Hénaff, 1991) and actual AA profiles of microbial protein in lactating dairy cows.

\section{MATERIAL AND METHODS}

\section{Experiment, animals, feed}

For the evaluation of actual and predicted amino acid content in the duodenal digesta, the data from previous studies (Třináctý et al., 2006, Křížová et al., 2007) were used. Cows, treatments and feeding regiment have been described previously (Tř̌ináctý et al., 2006). Briefly, treatment consisted of administrations of either rumen-protected tablets $(\mathrm{T})$ or powder (C) containing purified soya-protein HP 300 (Hamlet Protein A/S, Denmark) and amino acids Lys, Met and His into the rumen of three lactating Holstein cows (1-3 lactation, 17-35 week of lactation) of mean live weight $523 \mathrm{~kg}$ (SEM = 17) and milk yield $16.7 \mathrm{~kg}$. day $^{-1}$ (SEM $\left.=0.38\right)$. Cows were fitted with ruminal and duodenal T-cannulas (Komarek, 1981). The experiment was divided into 4 periods. Each period (14 d) consisted of 10-d preliminary period and 4-d experimental period. Cows were fed individually twice daily $(7.00$ and $16.35 \mathrm{~h})$ ad libitum a diet based on maize silage (54.7\%), lucerne hay (15.0\%) and concentrate (30.3\%). The experimental protein supplement consisted of ground soya protein HP 300 (93\%), Lys (1.6\%), Met (2.4\%) and His (3.0\%) and was prepared in two forms, either as rumen-protected tablets or powder. Tablets or powder together with chromic oxide (digesta passage marker) were wrapped into filter paper and inserted into the bottom of the rumen via ruminal cannula twice daily before feeding. Daily amount of these ingredients were as follows (g): HP 300 (306), Lys (5.7), Met (8.8), His (10.6) and chromic oxide (15.0).

In the previous study focused on the estimation of duodenal flow of soluble nitrogen fractions in the same experiment (Kř́žová et al., 2007), it has been found that in the case of ruminally protected tablets sampling from the duodenal cannula was unrepresentative. Thus for the evaluation of actual and predicted amino acid content in the duodenal digesta only the data from the control group of animals $(\mathrm{C})$ receiving the supplement in the powder form were used.

\section{Collection, processing and analyses of samples}

Feed samples were collected on the third day of each experimental period. Respective orts from each cow were collected and weighed during the four-day experimental period before each meal and stored in a freezer. After the experimental period, the orts were pooled for each cow, homogenized and the representative sample was taken.

The rumen fluid samples (1l) were collected from each cow once a day, during the four-day experimental period with a $2 \mathrm{~h}$ time shift between the successive days (at 9.00, 11.00, 13.00 and $15.00 \mathrm{~h}$ ). To the $500 \mathrm{ml}$ of rumen fluid sample the same volume of $0.95 \% \mathrm{NaCl}$ solution were added. The mix- ture was stirred in the blender and filtered through 4 layers of tissue, and then stored at $-20^{\circ} \mathrm{C}$ (Cecava et al., 1990). After thawing the samples were processed according to Schwab et al. (1992). The samples of microbial mass were pooled for each cow and experimental period, freeze-dried and homogenized.

The samples of duodenal digesta $(500 \mathrm{ml})$ were collected during the 4-day experimental period at $6 \mathrm{~h}$ intervals from each cow and immediately frozen to $-20^{\circ} \mathrm{C}$ (Schwab et al., 1992).

Processing of feed, feed refusals and duodenal chymus samples for analyses has been described in details elsewhere (Kř́žzvá et al., 2007). In feed and feed refusals samples the following parameters were estimated according to AOAC (1984): dry matter (DM), ash, crude protein (CP), fat (F) and crude fibre (CF). Neutral detergent fibre (NDF) with $\alpha$-amylase and acid detergent fibre (ADF) were estimated according to Van Soest et al. (1991). Content of Cr in samples of duodenal chymus were estimated according to Williams et al. (1962). Ammonia nitrogen content in duodenal chymus was estimated in a water eluate $\left(2 \mathrm{~g} .100 \mathrm{ml}^{-1}\right.$ of distilled water) using a gas electrode (manufacturer Radelkis Ltd., Hungary). $\mathrm{DM}$, ash and CP contents in the microbial mass and digesta were determined using the same procedure as in feeds. In samples of feeds, microbial mass and duodenal chymus content of individual AA was determined. Samples were adjusted using acidic and oxidative acidic hydrolysis. The chromatographic analysis of sample hydrolysates was performed in the analyser AAA 400 (INGOS Prague, CR) and using Na-citrate buffers and ninhydrin detection.

\section{Calculations}

PDIA, PDIN and PDIE values were calculated on the basis of chemical analysis results using regressions from the PrévAlim tool of the diet formulation software INRAtion (Baumont et al., 1999) and feed tables (Jarrige, 1990). A prediction of individual AA content in duodenal digesta protein was calculated using the equations published by Rulquin et al. (1998) by introduction of either mean values of individual AA concentration in microbial protein reported by Le Hénaff (1991) or those determined in this experiment (Tab. II). The above mentioned mathematical model does not implicate a biliary secretion because as the only source of endogenous AA the epithelium of various forestomach compartments and abomasum is used (Ørskov et al., 1986). Due to placing the duodenal T-cannula (distally to the bile duct) in this experiment the digesta samples were contaminated with bile (in particular with the conjugate of Gly and choline acids). In case of this type of endogenous fraction, there was not enough information published for us to be able to modify the mathematical prediction model. For this reason, a correction for Gly content in the bile was carried out on the side of the determined values of the duodenal AA flow before calculating the AA composition of duodenal protein. The Gly flow determined experimentally was corrected for its con- 
tent in bile (Larsen et al., 2000) by subtracting the following values from the total flow value:

$$
\mathrm{GlyI}_{\mathrm{b}}=\mathrm{GlyI}_{\mathrm{E}} \times 0.23 \times 0.307 \times 0.892,
$$

where $\mathrm{GlyI}_{\mathrm{b}}=$ the flow of Gly originating from the bile (g.day ${ }^{-1}$ ); GlyI $_{\mathrm{E}}=$ the experimental (determined) duodenal flow of Gly (g.day ${ }^{-1}$ ); 0.23 = mean proportion of endogenous AA in the total AA duodenal flow; 0.307 = mean proportion of bile AA in the endogenous AA flow; $0.892=$ mean proportion of Gly in the sum of bile AA.

\section{Statistical analyses}

For the statistical analyses the GLM procedure of the statistics software SYSTAT 11.00.01. (U.S.A.) was used. As a model for the comparison of true and predicted (by two methods) concentrations of individual AA in the duodenal digesta the following equation was used: $Y_{i j k}=\mu+M_{i}+C_{j}+R_{k}+\varepsilon_{i j k}$, where $\mu$ general mean, $M_{i}=$ method effect $(i=3), C_{j}=$ cow effect $(j=3), R_{k}=$ replication effect $(k=2), \varepsilon_{i j k}=$ residual error.

\section{RESULTS AND DISCUSSION}

\section{Basic parameters}

Basic parameters studied in this trial such as dry matter intake (DMI) (Tab. I), nitrogen intake (20.0 g. $\mathrm{kg}^{-1}$ of DMI, SEM = 0.39, $\left.\mathrm{n}=24\right)$ and non--ammonia nitrogen (NAN) duodenal flow $\left(19.7 \mathrm{~g} . \mathrm{kg}^{-1}\right.$ of DMI, SEM $=0.81, \mathrm{n}=6$ ) were similar to the values for cattle summarised from literature sources and reported by Rulquin et al. (1998).

I: Dry matter and nutrients intake

\begin{tabular}{llcc}
\hline \multirow{2}{*}{ Nutrient } & \multirow{2}{*}{ Unit } & \multicolumn{2}{c}{ Values $^{\mathbf{1}}(\mathbf{n}=\mathbf{2 4})$} \\
\cline { 3 - 4 } Dry matter & $\mathrm{kg} \cdot \mathrm{day}^{-1}$ & 15.68 & 0.32 \\
Organic matter & $\mathrm{kg} \cdot \mathrm{day}^{-1}$ & 14.59 & 0.30 \\
Crude protein & $\mathrm{kg} \cdot \mathrm{day}^{-1}$ & 1.89 & 0.05 \\
Fat & $\mathrm{kg} \cdot \mathrm{day}^{-1}$ & 0.54 & 0.01 \\
Crude fiber & $\mathrm{kg} \cdot \mathrm{day}^{-1}$ & 2.29 & 0.06 \\
NDF & $\mathrm{kg} \cdot \mathrm{day}^{-1}$ & 5.23 & 0.12 \\
ADF & $\mathrm{kg} \cdot \mathrm{day}^{-1}$ & 3.14 & 0.07 \\
Ash & $\mathrm{kg} \cdot \mathrm{day}^{-1}$ & 1.09 & 0.02 \\
PDIN $^{2}$ & $\mathrm{~kg} \cdot \mathrm{day}^{-1}$ & 1.25 & 0.02 \\
PDIE $^{2}$ & $\mathrm{~kg} \cdot \mathrm{day}^{-1}$ & 1.31 & 0.02 \\
NEL $^{3}$ & $\mathrm{MJ} \cdot$ day $^{-1}$ & 98.89 & 2.05 \\
\hline
\end{tabular}

${ }^{1}$ Values adapted from work of Třináctý et al. (2006)

${ }^{2}$ Protein truly digestible in the small intestine (Jarrige et al., 1989)

${ }^{3}$ Net energy for lactation

\section{Amino acid composition of microbial protein}

Because of a high proportion of the microbial protein in NAN entering the small intestine ranging from 34 to $89 \%$ (Clark et al. 1992), and the variability in its AA composition (Clark et al., 1992; Rulquin \& Vérité, 1993), this component can be regarded as the greatest source of variability in the prediction of individual AA concentrations in the duodenal digesta. The actual AA composition of microbial protein determined in our study was compared with the AA composition found by Le Hénaff (1991) and is presented in Tab. II. All the determined mean values of AA content are within the reported range.

\section{Experimental amino acid composition of duodenal digesta protein}

The experimental AA composition of duodenal digesta determined in our study $\left([\mathrm{AAI}]_{\mathrm{E}}\right)$ is presented in Tab. III. Mean values (g.100 g-1 of total AA) of Arg (6.18 vs. 4.92), and Gly (7.35 vs. 6.23) found in our experiment were higher and Met (1.66 vs. 1.93), Ileu (5.13 vs. 5.42) and Glu (12.6 vs. 14.6) were lower than the means reported by Rulquin et al. (1998), respectively. Nevertheless all mean values are within a range of values and the coefficients of variation (CV) are lower than those reported by Rulquin et al. (1998). A higher CV was found only for Gly (18.2 vs. $14.1 \%$, resp.) and Met (15.4 vs. $13.1 \%$, resp.). Because the diet composition was relatively constant throughout the trial it can be assumed that the main source of the increased variability of these two AA contents is their higher variability in the microbial protein found in this experiment (Tab. II).

\section{Comparison of the prediction accuracy calculated using the published and actual AA profiles of microbial protein}

The predicted values $[\mathrm{AAI}]_{\mathrm{P} 1}$ of Arg, Ileu, Leu, Met, Phe, Thr, Val, Glu, Pro, Ser and Tyr calculated from published microbial AA profile (Le Hénaff, 1991) were significantly different $(P<0.05)$ from the experimentally determined ones $\left([\mathrm{AAI}]_{\mathrm{E}}\right)$. On the other hand the $[\mathrm{AAI}]_{\mathrm{Pl}}$ and $[\mathrm{AAI}]_{\mathrm{E}}$ values of other AA (His, Leu, Lys, Thr, Val, Ala, Asp a Gly) were not significantly different $(P>0.05)$. This is in disagreement with Rulquin et al. (1998) who found that the mentioned values of only 3 AA (His, Val, Asp) did not differ significantly. Actually, mean relative difference between the values $[\mathrm{AAI}]_{\mathrm{Pl}}$ and $[\mathrm{AAI}]_{\mathrm{E}}$ was $7.36 \%$ and was higher than the published one (4.1\%). The main cause of a lower prediction accuracy was $\operatorname{Arg}(-25.7 \%)$ followed by Met $(22.5 \%)$ and Gly (-17.3\%). Rulquin et al. (1998) reported the prediction accuracy for most AA within 5 to $6 \%$ (13 cases). The same prediction accuracy was observed in 12 AA in this trial (Tab. III).

As to the difference between predicted AA composition calculated from experimentally determined AA composition of microbial protein $[\mathrm{AAI}]_{\mathrm{P} 2}$ and values $[\mathrm{AAI}]_{\mathrm{E}}$, loss of significance $(\mathrm{P}>0.05)$ for Ileu a Lys and its obtaining $(P<0.05)$ for Leu, 
II: Amino acid composition of endogenous and microbial protein (g.100 $\mathrm{g}^{-1}$ of total AA)

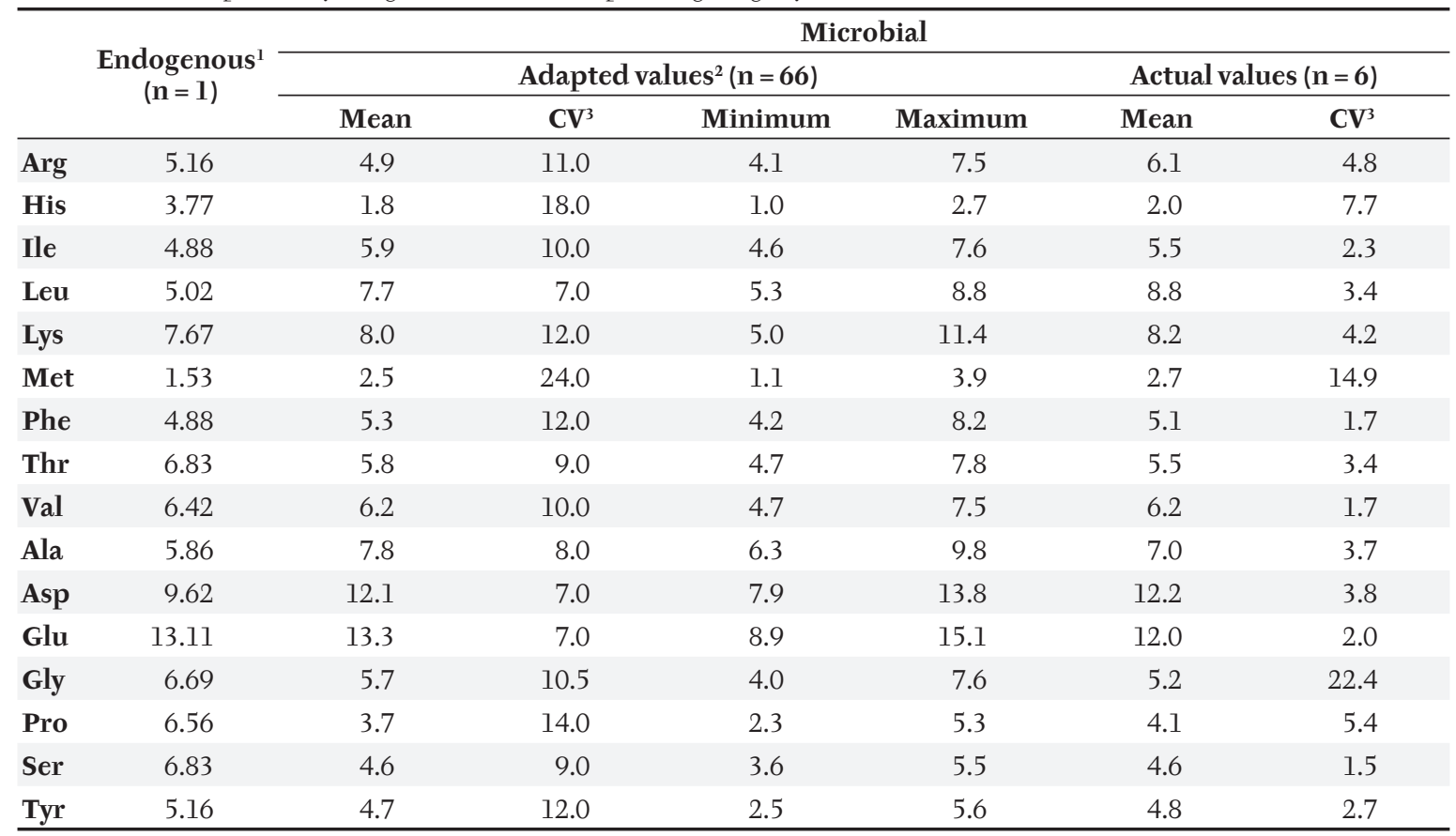

${ }^{1}$ Adapted from work of Ørskov et al. (1986)

${ }^{2}$ Adapted from work of Le Hénaff (1991)

${ }^{3}$ Coefficient of variation

III: Comparison of AA composition of the duodenal digesta (g.100 $g^{-1}$ of total $\left.A A, n=6\right)$ determined experimentally or predicted by two methods using published and actual microbial protein composition

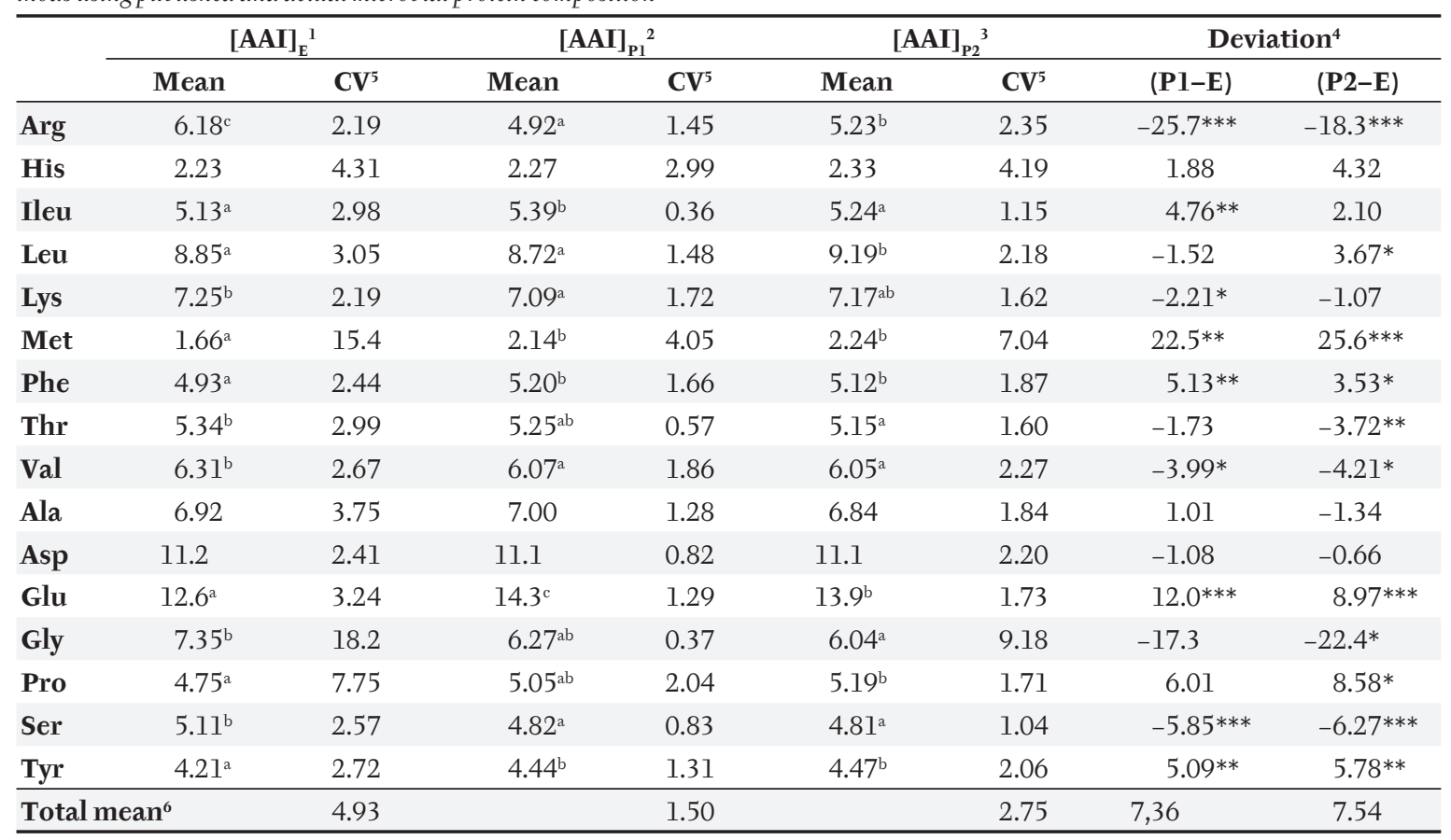

${ }^{1}[\mathrm{AAI}]_{\mathrm{E}}$ - in experiment determined AA concetration in the duodenal digesta

${ }^{2}[\mathrm{AAI}]_{\mathrm{P} 1}$ - predicted AA concentration using microbial AA composition according to LeHenaff (1991) in calculation

${ }^{3}[\mathrm{AAI}]_{\mathrm{P} 2}$ - predicted AA concentration using actual (in experiment determined) microbial AA composition in calculation

${ }^{4}$ Deviations (\%): $(\mathrm{P} 1-\mathrm{E})=100 \mathrm{x}\left([\mathrm{AAI}]_{\mathrm{P} 1}-[\mathrm{AAI}]_{\mathrm{E}}\right) /[\mathrm{AAI}]_{\mathrm{P} 1} ;(\mathrm{P} 2-\mathrm{E})=100 \mathrm{x}\left([\mathrm{AAI}]_{\mathrm{P} 2}-[\mathrm{AAI}]_{\mathrm{E}}\right) /[\mathrm{AAI}]_{\mathrm{P} 2}$; deviations statistically

different from zero: ${ }^{*} \mathrm{P}<0.05,{ }^{* *} \mathrm{P}<0.01,{ }^{* * *} \mathrm{P}<0.001$

${ }^{5}$ Coefficient of variation

${ }^{6}$ Total average of deviations $=\Sigma$ ABS(Deviation) $/ 16$

${ }^{\mathrm{a}, \mathrm{b}, \mathrm{c}}$ Means in the same row followed by the different superscripts differ significantly $(\mathrm{P}<0.05)$ 
Thr, Gly and Pro in comparison with differences of the values $[\mathrm{AAI}]_{\mathrm{pl}}$ was observed (Tab. III). Thus frequency of non-significant differences decreased from 7 to 5 AA. Mean relative difference between $[\mathrm{AAI}]_{\mathrm{P} 2}$ values and $[\mathrm{AAI}]_{\mathrm{E}}$ values was $7.54 \%$, i.e. comparable with $[\mathrm{AAI}]_{\mathrm{PI}}$ values $(7.36 \%)$ and higher than the value of $4.1 \%$ reported by Rulquin et al. (1998). Using experimentally determined AA composition of microbial protein the accuracy of prediction was improved only for Arg, Ile, Lys, Phe and Asp, whereas for the rest of AA was impaired (Tab. III). In the case of Gly the accuracy of prediction declined and the difference found $(-22.4 \%)$ was higher than that reported by Rulquin et al. (1998) being $-13.3 \%$. Because the prediction was underestimated it is probable that the correction for Gly content in the bile was insufficient. Larsen et al. (2000) and Olsson (1988) reported a great variability in the amount of bile formed and Gly contained in the bile both among different animals and within one animal, depending on a diet and stage of lactation. Because of low number of literature sources in this area it was impossible to consider the above-mentioned factors in the resulting mean value for Gly from bile, which might have lead to the insufficient correction.

\section{Effect of amino acid profile of undegraded feed protein}

Although the prediction accuracy for Arg concentration in $[\mathrm{AAI}]_{\mathrm{P} 2}$ was improved the difference from the reported value (Rulquin et al. 1998) remained relatively great (-18.3 vs. $5.6 \%$, resp.). In the case of Leu, the final difference between the predicted value and the one determined in this trial was relatively small (3.67\%), but the prediction accuracy was two times worse by using the actual composition of microbial protein (Tab. III). Based on these results it can be assumed that beside microbial mass there is another source of variability that influences the prediction accuracy. In this study a simplified determination of AA profile of undegraded feed protein was used assuming the same rate of degradation for each AA in whole protein. This simplification may cause either overestimation or underestimation of some AA contents in undegraded feed protein (Rulquin \& Vérité, 1993). The use of the data biased in this way may worsen the resulting prediction accuracy. Rulquin et al. (1998) reported that for Arg, the consequence of the above-mentioned phenomenon was regular overestimation of prediction and for Leu regular underestimation, which was demonstrated by their results. However, the results of this study showed an opposite trend: prediction of Arg concentration was underestimated unlike the one (-18.3 vs. $5.6 \%$, resp.) reported by Rulquin et al. (1998) and that of Leu was overestimated (3.67 vs. $-5.8 \%$, resp), which indicates a higher Arg content and lower Leu content in undegraded feed protein as compared with the expected ones. Indeed, Van Straalen et al. (1997) using the nylon-bag method found for maize silage (majority component of the experimental diet) a very low degree of degradation of Arg (41\%) and a higher degree of degradation of Leu (80\%) as compared with total feed protein degradation (74\%), which is in agreement with the above mentioned trends.

\section{CONCLUSION}

In comparison to the reported mean value of microbial protein composition the use of the actual one for prediction of AA composition of protein fraction flowing into the small intestine did not contribute to an improvement of calculation accuracy. Inaccurate determination of AA composition of undegraded feed protein and the insufficient correction for Gly of bile origin were the probable sources of the residual variability.

\section{SUMMARY}

The aim of this study was to compare the experimental and predicted AA profiles of the digesta entering the small intestine and compare the accuracy of prediction when using the published mean and actual AA profiles of microbial protein in lactating dairy cows. Three lactating Holstein cows (mean live weight $523 \mathrm{~kg}$, milk yield $16.7 \mathrm{~kg}$. day ${ }^{-1}$ ) fitted with ruminal and duodenal T-cannulas were fed individually twice daily ad libitum a diet based on maize silage (54.7\%), lucerne hay (15.0\%) and concentrate $(30.3 \%)$. Treatment consisted of administrations of powder containing purified soya-protein HP 300 (93\%), Lys (1.6\%), Met (2.4\%) and His (3.0\%) into the rumen. Powder together with chromic oxide (digesta passage marker) were wrapped into filter paper and inserted into the bottom of the rumen via ruminal cannula twice daily before feeding. The experiment was divided into 4 periods. Each period (14d) consisted of 10-d preliminary period and 4-d experimental period. Feed samples were collected on the third day of each experimental period. Respective orts from each cow were collected and weighed during the four-day experimental period. The rumen fluid samples (1l) were collected from each cow once a day, during the four-day experimental period with a $2 \mathrm{~h}$ time shift between the successive days (at $9.00,11.00,13.00$ and $15.00 \mathrm{~h}$ ). To the $500 \mathrm{ml}$ of rumen fluid sample the same volume of $0.95 \% \mathrm{NaCl}$ solution were added. The mixture was stirred in the blender and filtered through 4 layers of tissue, and then stored at $-20^{\circ} \mathrm{C}$. After thawing microbial mass was separated from the samples according to Schwab et al. (1992) and was pooled for each cow and experimental period, freeze-dried and homogenized. The samples of duodenal digesta $(500 \mathrm{ml})$ were collected during the 4-day experi- 
mental period at $6 \mathrm{~h}$ intervals from each cow and immediately frozen to $-20^{\circ} \mathrm{C}$. In feed and feed refusals samples the following parameters were estimated: dry matter, ash, crude protein, fat and crude fibre, NDF (with $\alpha$-amylase) and ADF. AA profiles of feeds, mikrobial mass protein and of duodenal digesta protein were determined. AA profile of duodenal protein was corrected for glycine of bile origin. Prediction of duodenal digesta AA profile according to Rulquin et al. (1998) was calculated using the published mean and actual AA profiles of microbial protein. Results were compared using GLM procedure according to the following model: $Y_{i j k}=\mu+M_{i}+C_{i}+R_{k}+\varepsilon_{i j k}$, where $\mu=$ general mean, $M_{i}$ $=$ method effect $(i=3), C_{j}=$ cow effect $(j=3), R_{k}=$ replication effect $(k=2), \varepsilon_{i j k}=$ residual error.

The actual AA composition of microbial protein determined in our study was compared with the AA composition found by Le Hénaff (1991). All the determined mean values of AA content were within the reported range. The predicted values of Arg, Ileu, Leu, Met, Phe, Thr, Val, Glu, Pro, Ser and Tyr calculated from published microbial AA profile $\left([\mathrm{AAI}]_{\mathrm{Pl}}\right)$ were significantly different $(\mathrm{P}<0.05)$ from the experimentally determined ones $\left([\mathrm{AAI}]_{\mathrm{E}}\right)$. Actually, mean relative difference between the values $[\mathrm{AAI}]_{\mathrm{P} 1}$ and $[\mathrm{AAI}]_{\mathrm{E}}$ was $7.36 \%$. The main cause of a lower prediction accuracy was Arg (-25.7\%) followed by Met (22.5\%) and Gly (-17.3\%). As to the difference between predicted AA composition calculated from experimentally determined AA composition of microbial protein $\left([\mathrm{AAI}]_{\mathrm{P} 2}\right)$ and values $[\mathrm{AAI}]_{\mathrm{E}}$, loss of significance $(\mathrm{P}>0.05)$ for Ileu a Lys and its obtaining $(\mathrm{P}<0.05)$ for Leu, Thr, Gly and Pro in comparison with differences of the values $[\mathrm{AAI}]_{\mathrm{p} 1}$ was observed. In the case of Gly the accuracy of prediction declined from -17.3 to $-22.4 \%$. Although the prediction accuracy for Arg concentration in $[\mathrm{AAI}]_{\mathrm{P} 2}$ was improved the difference remained relatively great (-18.3\%). Mean relative difference between $[\mathrm{AAI}]_{\mathrm{P} 2}$ values and $[\mathrm{AAI}]_{\mathrm{E}}$ values was $7.54 \%$, i.e. comparable with $[\mathrm{AAI}]_{\mathrm{P} 1}$ values $(7.36 \%)$. Thus in comparison to the published AA profile of microbial protein the use of the actual one did not contribute to an improvement of prediction accuracy.

\section{SOUHRN}

Porovnání aktuálního a predikovaného obsahu aminokyselin v duodenální trávenině laktujících dojnic

Cílem této práce bylo porovnat stanovený a predikovaný aminokyselinový profil tráveniny vstupující do tenkého střeva a porovnání přesnosti predikce př̀i použití průměrného publikovaného a aktuálního aminokyselinového složení mikrobiálního proteinu u laktujících dojnic. Tř̌i dojnice holštýnského plemene (živá hmotnost $523 \mathrm{~kg}$, dojivost 16,7 kg.den-1) s ruminální a duodenální kanylou byly individuálně krmeny ad libitum krmnou dávkou složenou z kukuřičné siláže (54,7\%), vojtěškového sena (15,0\%) a směsi (30,3\%). Experimentální zásah byl realizován přídavkem práškové směsi obsahující proteinový koncentrát HP 300 (93\%), Lys (1,6\%), Met (2,4\%) a His (3,0\%) do bachoru. Směs byla spolu s oxidem chromitým (marker pasáže tráveniny) zabalena do filtračního papíru a vkládána dvakrát denně před krmením přes ruminální kanylu na dno bachoru. Experiment byl rozdělen na čtyři periody. Každá perioda (14 d) se skládala z desetidenní návykové a čtydenní experimentální periody. Vzorky krmiv byly odebírány třetí den každé experimentální periody. Odpovídající zbytky od každé dojnice byly odebírány a váženy v průběhu čtyř dnů experimentální periody. Vzorky ruminální tekutiny (1litr) byly od každé dojnice odebírány jednou denně v průběhu čtyř dnů experimentální periody s dvouhodinovým časovým posunem každý následující den (9.00, 11.00, 13.00 a 15.00 h). K $500 \mathrm{ml}$ ruminální tekutiny bylo přidáno stejné množství 0,95\% roztoku NaCl. Směs byla míchána v mixeru, filtrována přes čtyři vrstvy plátna a potom zamražena na $-20^{\circ} \mathrm{C}$. Po roztání byla ze vzorků separována mikrobiální hmota dle Schwab et al. (1992), sloučena za každou dojnici a periodu, lyofilizována a homogenizována. Vzorky duodenální tráveniny ( $500 \mathrm{ml}$ ) byly odebírány od každé dojnice v průběhu čtyřdenní experimentální peridy v šestihodinových intervalech a ihned zamraženy na $-20^{\circ} \mathrm{C}$. Ve vzorcích krmiva a zbytků byly stanoveny následující parametry: sušina, popel, N-látky, tuk, vláknina, NDF (s $\alpha$-amylázou) a ADF. U vzorků krmiv, mikrobiální hmoty a duodenální tráveniny byly stanoveny obsahy jednotlivých AA. Aminokyselinový profil duodenálního proteinu byl korigován na Gly pocházející ze žluči. Predikce obsahu AA v duodenální trávenině dle Rulquin et al. (1998) byla vypočítána s použitím publikovaného průměrného a aktuálního aminokyselinového složení mikrobiálního proteinu. Výsledky byly porovnány GLM procedurou dle následujícího modelu: $\mathrm{Y}_{\mathrm{ijk}}=\mu+\mathrm{M}_{\mathrm{i}}+\mathrm{C}_{\mathrm{j}}+\mathrm{R}_{\mathrm{k}}+\varepsilon_{\mathrm{ijk}}$, kde $\mu=$ celkový průměr, $\mathrm{M}_{\mathrm{i}}=$ faktor metody $(\mathrm{i}=3), \mathrm{C}_{\mathrm{j}}=$ faktor dojnice $(\mathrm{j}=3)$, $\mathrm{R}_{\mathrm{k}}^{\mathrm{ijk}}=$ faktor opakování $(\mathrm{k}=2), \varepsilon_{\mathrm{ijk}}=$ reziduální chyba.

Aktuální AA složení mikrobiálního proteinu stanovené v naší práci bylo porovnáno s AA složením publikovaným autorem Le Hénaff (1991). Všechny průměrné hodnoty obsahu AA byly v publikovaném rozpětí. Predikované hodnoty pro Arg, Ileu, Leu, Met, Phe, Thr, Val, Glu, Pro, Ser a Tyr vypočítané z publikovaného mikrobiálního AA profilu ([AAI $\left.]_{\mathrm{P} 1}\right)$ byly prokazatelně odlišné $(\mathrm{P}<0,05)$ od experimentálně stanovených $\left([\mathrm{AAI}]_{\mathrm{E}}\right)$. Průměrná relativní odchylka mezi hodnotami $[\mathrm{AAI}]_{\mathrm{Pl}} \mathrm{a}[\mathrm{AAI}]_{\mathrm{E}}$ činila 7,36\%. Hlavní př́íčinou nižší přesnosti predikce byl Arg (-25,7\%) následovaný Met (22,5\%) a Gly (-17,3\%). Na základě porovnání predikovaného AA složení vypočítaného z experimentálně stano- 
veného AA složení mikrobiálního proteinu $\left([\mathrm{AAI}]_{\mathrm{P} 2}\right) \mathrm{s}$ hodnotami $[\mathrm{AAI}]_{\mathrm{E}}$ byla zjištěna ztráta signifikance $(\mathrm{P}>0,05)$ pro Ileu a Lys a naopak signifikantní rozdíl $(\mathrm{P}<0,05)$ byl zaznamenán pro Leu, Thr, Gly a Pro. V př́padě Gly klesla přesnost predikce z - $17.3 \%$ na $-22.4 \%$. Přestože se přesnost predikce u Arg v př́padě $[A A I]_{\mathrm{p} 2}$ zvýšila, rozdíl zůstal relativně vysoký (-18,3\%). Průměrný relativní rozdíl mezi hodnotami $[\mathrm{AAI}]_{\mathrm{P} 2}$ a $[\mathrm{AAI}]_{\mathrm{E}}$ činil 7,54\% a byl srovnatelný s hodnotami $[\mathrm{AAI}]_{\mathrm{P} 1}(7,36 \%)$. Z výsledkủ vyplývá, že použití aktuálního AA profilu mikrobiálního proteinu ve srovnání publikovaným nepřispělo k zvýšení přesnosti predikce.

aminokyseliny, dojnice, duodenum, mikrobiální protein, predikce

\section{Acknowledgements}

The authors would like to express their thanks to Ing. S. Pavlok and Ing. S. Hadrová for samples processing and analysing and to V. Hlaváček for samples collecting. This research was supported by the Ministry of Education, Youth and Sports of Czech Republic (Project No. MSM 2678846201) and the National Agency for Agriculture Research, Czech Republic (Project No. 1B44037).

\section{REFERENCES}

AOAC, 1984: Association of Official Analytical Chemists. Official Method of Analysis, 14th Edition. AOAC, Washington DC, USA. ISBN 0-935584-24-2.

BAUMONT, R., CHAMPCIAUX, P., AGABRIEL, J., ANDRIEU, J., AUFRÈRE, J., MICHALET-DOREAU, B. AND DEMARQUILLY, C., 1999: Une démarche intégrée pour prévoir la valeur des aliments pour les ruminants. PrévAlim pour INRAtion. Productions Animales. 12, 183-194. ISSN 09900632.

CECAVA, M. J., MERCHEN, N. R., GAY, L. C. and BERGER, L. L., 1990: Composition of ruminal bacteria harvested from steers as influenced by dietary energy level, feeding frequency, and isolation techniques. Journal of Dairy Scince, 73: 24802488. ISSN 0022-0302.

CLARK, J. H., KLUSMEYER, T. H. and CAMERON, M. R., 1992: Microbial protein synthesis and flows of nitrogen fractions to the duodenum of dairy cows. Journal of Dairy Scince, 75: 2304-2323. ISSN 0022-0302.

JARRIGE, R. (ED.), 1989: Ruminant nutrition. Recommended allowances and feed tables. INRA, John Libbey Eurotext, Paris, 400 pp. ISBN 0-86196-247-8.

KOMAREK, R. J., 1981: Intestinal cannulation of cattle and sheep with a T-shaped cannula designed for total digesta collection without externalizing digesta flow. Journal of Animal Science, 53: 796-802. ISSN: 0021-8812.

KŘİŽOVÁ, L., RICHTER, M., TŘINÁCTÝ, J., ŠTERC, J. and HADROVÁ, S., 2007: The effect of soya protein supplement enriched with three amino acids on duodenal flow of soluble nitrogen fractions and amino acids in dairy cows. Journal of animal and feed sciences, 16: 346-357. ISSN 1230-1388.

LARSEN, M., MADSEN, T. G., WEISBJERG, M. R., HVELPLUND, T. and MADSEN, J., 2000: Endogenous Amino Acid Flow in the Duodenum of Dairy Cows. Acta Agriculturae Scandinavica Section A-Animal Science, 50, 161-173. ISSN 0906-4702.
LE HÉNAFF, L., 1991: Importance des acides aminés dans la nutrition des vaches latières. Thèse de docteur 3 e cycle No 254. Université de Rennes, Rennes, 125 pp. No: 91 REN1 0057.

OLSSON, T., 1988: Serum bile acids in cattle. diurnal variations and variations due to stage of lactation. Zentralblatt für Veterinärmedizin, 35: 467-472. ISSN 0514-7158.

ØRSKOV, E. R., MACLEOD, N. A. and KYLE, D. J., 1986: Flow of nitrogen from the rumen and abomasum in cattle and sheep given protein-free nutrients by intragastric infusion. British Journal of $\mathrm{Nu}$ trition, 56: 241-248. ISSN 0007-1145.

RULQUIN, H.P., GUINARD, J. and VÉRITÉ, R., 1998: Variation of amino acid content in the small intestine digesta of cattle. development of a prediction model. Livestock Production Science, 53: 1-13. ISSN 0301-6226.

RULQUIN, H. P., PISULEWSKI, M., VÉRITÉ, R. AND GUINARD, J., 1993: Milk production and composition as a function of postruminal lysine and methonine supply: A nutrient-response approach. Livestock Production Science, 37: 69-90. ISSN 0301-6226.

RULQUIN, H. P. and VÉRITÉ, R., 1993: Amino acid nutrition of dairy cows. productiv effects and animal requirements. In: GARNSWORTHY, P. C. and COLE, D. L. A. (eds.) Recent advances in animal nutrition. Nottingham University Press, Nottingham, pp. 55-77. ISBN 9781897676004.

SCHWAB, C. G., BOZAK, C. K. and WHITEHOUSE, N. L., 1992: Amino Acid Limitation and Flow to Duodenum at Four Stages of Lactation. 1. Sequence of Lysine and Methionine Limitation. Journal of Dairy Scince, 75: 3486-3502. ISSN 0022-0302. TŘINÁCTÝ, J., KŘİŽOVÁ, L., HADROVÁ, S., HANUŠ, O., JANŠTOVÁ, B., VORLOVÁ, L. and DRAČKOVÁ, M., 2006: Effect of rumen-protected protein supplemented with three amino acids on milk yield, composition and fatty acid profile in dairy cows. Journal of animal and feed sciences 15 : 3-15. ISSN 1230-1388. 
VANHATALO, A., HUHTANEN, P., TOIVONEN, V. and VARVIKKO, T., 1999: Response of Dairy Cows Fed Grass Silage Diets to Abomasal Infusions of Histidine Alone or in Combinations with Methionine and Lysine. Journal of Dairy Scince, 82: 2674 2685. ISSN 0022-0302.

VAN SOEST, P. J., ROBERTSON, J. B. and LEWIS, B. A., 1991: Symposium. Carbohydrate methodology, metabolism, and nutritional implications in dairy cattle. Methods for dietary fiber, neutral detergent fiber, and nonstarch polysaccharides in relation to animal nutrition. Journal of Dairy Scince, 74: 3583-3597. ISSN 0022-0302.
VAN STRAALEN, W. M., ODINGA, J. J. and MOSTERT, W., 1997: Digestion of feed amino acids in the rumen and small intestine of dairy cows measured with nylon-bag techniques. British Journal of Nutrition, 77: 83-97. ISSN 0007-1145.

WILLIAMS, C. H., DAVID, D. J. and IISMAA, O., 1962: The determination of chromic oxide in faeces samples by atomic absorption spectrophotometry. Journal of Agricultural Science 59, 381-385. ISSN 0021-8596.

Address

Ing. Michal Richter, Dr. Ing. Jiří Třináctý, Mgr. Ing. Ludmila Kř̌ižová, Ph.D., Agrovýzkum Rapotín, s. r. o., Oddělení fyziologie výživy zvířat a kvality živočišných produktů, Vídeňská 699, 69123 Pohořelice, Česká republika, e-mail: richter@vuvz.cz 